\title{
МОНГОЛ ОРНЫ ЗАЛУУ ШИНЭСЭН ОЙ ҮУСЭН БУРЭЛДЭХ ЯВЦ БА ӨСӨЛТИЙН ЯВЦЫН ЗАРИМ ОНЦЛОГ
}

\author{
13.Цогт, ${ }^{2}$ И.М.Данилин \\ ${ }^{l}$ Ботаникийн хүрээлэн, ${ }^{2}$ Красноярскийн ойн хүрээлэн \\ Цахим иуудан: tsogt_zan@yahoo.com
}

\section{ОРШИЛ}

Сүүлийн үед ой үүсэн бүрэлдэх явц түүний бүтээмжийг дээшлүүлэх асуудалд судлаачид ихээхээн анхаарал тавих боллоо. Ялангуяа хөрш зэргэлдээх Орос орны эрдэмтэд дээрх чиглэлийн судалгааг 1960аад оноос эхлэн эрчимтэй явуулж, нилээд ном бүтээл хэвлэн нийтлүүлжээ $(2,8,9,13$, 16,19 ). Гэвч тэдгээр ном бүтээлд гол төлөв нарс, хуш, гацуур, жодоо, хус, улиангаран ойн талаар өгүүлж, манай оронд өргөн тархсан сибир шинэсний тухай бараг хөндөгдөөгүй байна.

Монгол орны залуу шинэсэн ой үүсэн бүрэлдэх явц ба өсөлтийн явцын судалгааны ажил 1979 оноос Монгол-Оросын хамтарсан Биологийн иж бүрэн экспедицийн ойн хэсгийн судалгааны ажлаар эхэлсэн ба тодорхой бүс нутгийн шинэсэн ойн өсөлт хөгжилтийн талаар Е.Н.Савин (1985), И.М.Данилин (1992), И.М.Данилин, З.Цогт (1992), З.Цогт (1993), Ч.Дугаржав (1996), Ч.Доржсүрэн (2009), В.Т.Ярмишко ба бусад (2010). И.М.Данилин (2009) нарын бүтээлд тодорхой хэмжээгээр тусгагдсан байдаг.

Ой-ургамалжилтын ижил нөхцөлд үүсэн бүрэлдэж буй ойг судлахдаа түймрийн дараах, огтлолтын дараах, ямарч нөлөөнд өртөөгүй гэх мэтээр авч үзэж судлах нь зүйтэй байна.

Бид өөрсдийн судалгаагаар ой үүсэн бүрэлдэх явцын тодорхой хэсэг хугацааны буюу залуу ой бүрэлдэх өсөлт, хөгжилтийн онцлогийг илрүүлэх зорилтыг тавьсан юм. Янз бүрийн бүрэлдэхүүнтэй залуу ойн үүсэн бүрэлдсэн байдлыг илрүүлэх, тэдгээрийн таксацын бүтцийн үндсэн үзүүлэлтийг тодорхойлох нь ойн нөөцийг тасралтгүй ашиглах, хамгаалах, нөөцийг нэмэгдүүлэх, бүтээмжит чанарыг дээшлүүлэх зэрэг ой судлалын олон асуудлыг шийдвэрлэхэд онолын төдийгүй практикийн чухал ач холбогдолтой. Мод огтолсон, түймэрт шатсан ойн талбай, тэрчлэн ойн зах цоорхойд байгалийн замаар залуу ой үүсэн бүрэлдэх явц бол биогеоценозын маш нарийн үйл явц юм.

\section{СУДАЛГААНЫ АРГАЗУЙ, ЦУГЛУУЛСАН МАТЕРИАЛ}

Судалгааны талбай тусгаарлах, ойн таксацын бүтэц, өсөлт хөгжилтийн явцыг тодорхойлоход Н.П.Анучин (1977), А.В.Побединский (1966) нарын аргазүйг ашиглав.

Энэхүу судалгааны ажил Ботаникийн хүрээлэнгийн эрдэм шинжилгээний сэдэвт ажил болон Монгол-Оросын хамтарсан Биологийн иж бүрэн экспедицийн хөтөлбөрийн дагуу Завхан аймгийн Тосонцэнгэл дэх ойн суурин цэгт 1979 оноос, Төв аймгийн Мөнгөнморьт дахь ойн суурин цэгт 1980 оноос эхлэн өнөөг хүртэл хийгдэж байна. Тус бүс нутгуудын залуу шинэсэн ойд байгуулсан байнгын ажиглалтын 0.020.50 га хэмжээтэй нийт 21 талбайд 3-5 удаa (3 жил, 4 жил, 10 жил, 22 жил, 27 жилийн дараа) таксацын хэмжилт тооллогыг давтан хийсэн болно. Энэ хугацаанд ойн моддын өсөлтийг явцыг тодорхойлох зорилгоор нийт 950 ширхэг загвар мод, 84 ширхэг ишний шинжилгээний дээж мод авсан.

\section{СУДАЛГААНЫ ҮР ДУН}

Залуу ой үүсэн бүрэлдэх онщлог. Төв Хангай, Дорнод Хэнтэйн түймэрт нэрвэгдсэн 0.3-0.4 өтгөрөлтэй нас гүйцсэн 
хөгшин ойд сэргэн ургалтын үйл явц хангалттай сайн, өсвөр мод талбайд жигд тархжээ. Дорнод Хэнтэйн мод бэлтгэсэн талбайд залуу шинэсэн ой, хус-шинэсэн ой, хусан ой, мөн түүнчлэн ойн жижиг цоорхой, ойн хормойгоор шинэсэн ой янз бүрийн шигүүрэлтэйгээр үүсэн бүрэлдэж байна. Түймэр олон удаа давтагдан гарсан газар шинэсэн ой хусаар солигддог. Ялангуяа хээржсэн алаг өвст шинэсэн ой түймэрт их нэрвэгджээ. Цаг уурын нэн тааламжтай нөхцөл бүрдсэн жилд ой нь хээр рүҮ түрж ургаж байна.

Төв Хангайн нөхцөлд модыг нилэнхүйд нь огтолсон тохиолдолд ойн сэргэн ургалт зогсож, тэнд шууд хээрийн ургамал ургаж, хээржих үйл явц эрчимтэй явагджээ. Харин модыг түүвэрлэн огтолсон тохиолдолд сэргэн ургалт дан ганц шинэс модоор нөхөн сэргэдэг онцлогтой.

Залуу ой үүсэн бүрэлдэх явц нь тухайн модлог ургамлын тархалт, биологийн шинж чанар, ургах орчны нөхцөлтэй нягт холбоотой. Төв Хангайд хус мод ургах тааламжгүй нөхцөлтэй учир дан ганц шинэс модоор үүсэн бүрэлдэж байна. Түүгээр зогсохгүй шинэс модоор сэргэн ургахдаа 1 га-д Хэнтэйгээс олон тооны өсвөр шинэс мод ургаж, өөрийн өсч хөгжих ойн орчноо бүрдүүлж байна. Түймэр олон удаа давтан гарсан нөхцөлд ойн бүслүүрийн дунд хэсгээр алтайн далан хальс, дээд бүслүүрээр нэрс, алирс зэрэг сөөг ургамал ургажээ.

Судалгааны зарим дүнгээс үзэхэд, 50-60 жилийн өмнө түймэр олон удаа гарч байжээ. Мод огтолсон ба түймэрт шатсан талбайд залуу ой үүсэн бүрэлдэхдээ гол төлөв их шигүүрэлтэй байна. Их шигүүрэлтэй ойн моддын өндөр, диаметр, нөөцийн өсөлт бага байдаг тул таваарлаг болон тэсвэрлэг чанар мууддаг. Энэ бүгдээс үзэхэд, Төв Хангайн байгаль цаг уур, экологийн нөхцөлд ургаж буй шинэс моддын өсөлт Дорнод Хэнтэйн моддоос доогуур болох нь илэрхий.

Бид судалгааг явуулахын тулд Монгол-Оросын хамтарсан биологийн иж бүрэн экспидецийн Мөнгөнморьт дахь ойн суурингийн судалгааны 2-р талбай, Тосонцэнгэл дэхь ойн суурингийн судалгааны 11-р талбайг сонгон авсан юм. Эдгээр цэгт залуу ой янз бүрийн бүрэлдэхүүнтэйгээр үүсэн бүрэлдэж байгаа учир дан шинэсэн, шинэс-хусан, дан хусан, мөн эх ойн том модны нөмөр дор 2-р ташинга үүсгэн ургаж буй шинэс-хусан, хус-шинэсэн ойд судалгааны дээж талбайг байгуулж, таксацын хэмжилт тооллогыг модны төрөл, ташинга тус бүрээр явуулсан юм.

Мөнгөнморьт дахь ойн суурингийн судалгааны 2-р талбайн ойн модод ойургамалжилтын нэг адил нөхцөлд ургана. Одоогоос 50 жилийн өмнө энд нас гүйцсэн хөгшин шинэс мод дангаараа ургаж байсныг зэргэлдээ ургаж буй эх ойн мод харуулна. Тэр үед тухайн хэвшинжийн ойд огтлолтыг янз бүрийн эрчимтэй, их бага хэмжээтэй хийжээ. Бид тэдгээрээс модыг нилэнхүйд нь огтолсон талбай, бараг нилэнхүйд нь (ойн нөөцийн 80 орчим хувийг огтолсон), түүвэрлэн огтолсон (ойн нөөцийн 45 орчим хувийг огтолсон) талбайд сэргэн ургасан янз бүрийн бүрэлдэхүүнтэй залуу ойг судалсан юм.

Огтлолтын эрчмийг ургаa үлдсэн том мод, өмхөрсөн хожуулын тооллогын дүнгээр тодорхойлов. Огтлолтын дараа түймэр гарсныг ургаа үлдсэн том моддын жилийн цагирагийн өсөлт, түймрийн шинж тэмдэгийн ажиглалтаар огтлолтын эрчмийг тогтоолоо. Мөн түймрийн дараах жилүүдэд тухайн районд чийглэг дулаан үед тохиолдсоныг цаг уурын станцын олон жилийн ажиглалтын материалаар климадиаграмм байгуулж тодорхойлсон юм.

Мод бэлтгэсэн талбай дээр ойн сэргэн ургах үйл явц олон үе шаттай явж байна. Залуу ойн үүсэн бүрэлдэх үйл явц нь ой-ургамалжилтын янз бүрийн нөхцөлд өөр өөр явагддагийг зарим судалгаа харуулав. Тухайлбал, Сибирийн ойд хийсэн судалгаанаас үзэхэд, ногоон хөвдөт хэвшинжийн ой модыг нилэнхүйд 
нь огтолсон, түймэрт шатсан талбай, цаг уурын тааламжтай жилийн нөхцөл болон элбэг үрийн жил тохиолдох үед үндсэн төрлөөрөө байгалийн аясаараа амжилттай сэргэж байхад, алирс-алаг өвст болон өвслөг хэвшинжийн шилмүүст ойн нилэнхүйд нь огтолсон талбайд гол төлөв хус, улиангараар сэргэн ургадаг ажээ $(10 ; 11 ; 12,18)$.

Бидний судалгааны бүх талбай ойургамалжилтын ижил нөхцөлд орших боловч, огтлолтын эрчим, түймрийн нөлөөнөөс хамаарч ойн бичил орчин нь өөрийн тодорхой хэвшинж үүсгэнэ. ЭнэхүУ бичил орчин дахь хэвшинж бүр бичил уур амьсгал, хөрс, шим бүлгэмдлийн хүчин зүйл, мөн түүнчлэн модлог ургамлын сэргэн ургах байгалийн тодорхой, өөрийн өвөрмөц өөрчлөлттэй байна.

Мод бэлтгэсэн талбайн хэвшинжүүд нь өөр хоорондоо бичил уур амьсгалын нөхцөл, чийг дулааны горим, хөрсний үржил шим, химийн шинж чанар, биологийн идэвхжил зэргээрээ ялгагдана. Эдгээр хүчин зүйлс нь ойн байгалийн сэргэн ургалтын үйл явцад ч, цухуйц, өсвөр модны өсөлтөнд ч нөлөө ҮзҮҮлнэ.

Ойн модыг огтлоход тухайн талбайн хөрс богино хугацаанд органик бодистой болдог. Энэ нь уг талбайд огтлолтоос үлдсэн модны хаягдал, үндэс, огтлох явцад хөнөөгдсөн өсвөр мод, өвс, хөвх, ялзарсны дүнд экологийн байдал эрс өөрчлөгдөж улмаар хөрсний биологи, биохимийн үйл явцын эрчим өөрчлөгдсөнөөр тайлбарлагдана. Өөрөөр хэлбэл ойн бүлгэмдлийн хүчин зүйлд тоо, чанарын өөрчлөлт гарч мод бэлтгэл явуулсан талбайд бичил цаг уур, хөрсний өвөрмөц нөхцөл үүсч улмаар өөрийн тодорхой хэвшинж, бичил орчин бий болно.

Дорнод Хэнтэйн хошууны хээржсэн алаг өвст хэвшинжийн шинэсэн ойд харилцан адилгүй эрчимтэй мод бэлтгэлийг явуулсны улмаас өвөрмөц бичил орчин Үүсч, улмаар түймэр, цаг уур болон бусад хүчин зүйлийн дүнд байгалийн аясаараа янз бүрийн бүрэлдэхүүнтэй хусан ойгоор сэргэжээ. Энэ нь навчит мод үргэлж арвин үрлэж, үр нь салхиар хол зайд тархахын зэрэгцээ ургал эрхтэнээр эрчимтэй үржиж, амьдралын эхний үедээ шилмүүст модноос өсөлтөөр хурдан байдаг зэрэгтэй шууд холбоотой. Түүнээс гадна шилмүүст модыг бодвол навчит төрлийн мод түймэрт шатсан талбайд амархан дасан зохицдог бөгөөд гэрэл, дулаан, чийгийн хангамж их шаарддаг онцлогтой.

Мод нилэнхүйд нь огтолсон талбайд хусан ой сэргэн ургаж ойн бүрэлдэхүүн 96Хс4Ш, дундаж диаметр 12.5 см, өндөр нь 12.25 м байна. Залуу хусан ойн өтгөрөл 1.1 байгаа нь ойн байгалийн аясаараа сийрэгжих үйл явц удаашралтайг харуулна.

Харин эХ ойгоос модыг бараг нэлэнхүйд нь огтолсон талбайд шинэс, хус мод бараг тэнцүүхэн ургаж ойн бүрэлдэхүүн 41Ш59Хс байна. Энэ нь огтлолтын дараа ургаа үлдсэн хэдхэн том модод ойн бичил орчинд нөлөөлж байгаагаас шинэс, хус моддын холилдон ургах таатай нөхцөлийг бүрдүүлсэнтэй холбоотой. УГ хоёр төрлийн мод ургах явцдаа бие биетэйгээ байнга өрсөлдөж хус нь, шинэс модноос өсөлтөөр давамгайлж байна. Иймд шинэс модны өсөлт хөгжилтөнд саатуулагч нөлөө үзүүлж буй аж ахуйн ач холбогдлоор бага хусыг арчилгааны огтлолтоор авч, шинэс модны өсөлтийг түргэсгэх шаардлагатай байна.

Эх ойн моддын нөөцийн 45 орчим хувийг түУвэрлэн огтолсон талбайд $76 Ш 24 Х c$ бүрэлдэхүүнтэй залуу ой 2-p ташинга үүсгэн ургах таатай нөхцөлийг бүрдүүлжээ. Ойн бүрэлдэхүүний хувьд шинэс мод бусад талбайнхаас хэдийгээр давамгайлж байгаа боловч, өндөр, диаметр зэрэг таксацын үндсэн үзүүлэлтээр бусад талбайнхаас доогуур байна.

Энэ нь залуу моддын өсөлт хөгжилтөнд ургаа үлдсэн эх ойн мод саатуулагч нөлөө Үзүүлж байгаатай холбоотой. Хэрвээ 1-р ташинга үүсгэн ургаж буй том моддыг огтолбол залуу моддын өсөлт, хөгжилт түргэсэн улмаар бүтэц, бүрэлдэхүүн нь сайжрах бол- 
HO.

Ойн элбэг үрийн жил тохиолдсон үед цухуйц, өсвөр мод сэргэн ургах цаг уурын тааламжтай нөхцөл бүрдсэнтэй холбоотойгоор эх ойн захаар шинэсэн ой үүсэн бүрдэж байна. Тухайн талбайн ой түймэрт өртөөгүй тохиолдолд моддын өсөлт хөгжилт нь бусад талбайн ойн моддоос сайн байна. Үүнийг ойн захаар сэргэн ургаж буй 40-50 насны шинэсэн ойн бүрэлдэхүүн: 90Ш10Хс, дундаж диаметр 11.8 м, дундаж өндөр 12.9 м, өтгөрөл 1.1, нөөц $221.0 \mathrm{~m}^{3} /$ га байгаагаас харж болно.

Хэдийгээр бусад талбайн шинэсний дундаж диаметрээс 2.6-6.2 см-ээр, дундаж өндрөөс 2.30-4.90 м-ээр их өсөлттэй байгаа ч гэсэн ойн өтгөрөл 1.1 байгаа нь уг ойд байгалийн аясаараа ойн сийрэгжих үйл явц явагдаж дуусаагүйг харуулж, арчилгааны огтлолт явуулах шаардлагатайг илтгэнэ.

Тосонцэнгэл дэхь ойн суурингийн судалгааны 11-р талбайн ойд одоогоос 50-60 жилийн өмнө түймэр гарч эх ойн том моддыг үндсэнд нь устгаж, үүний дараа шинэсэн ой үүсэн бүрэлджээ. Энэ нь тухайн үед амьд үлдсэн хэдхэн тооны том мод элбэг үрлэж, үр ургах, цухуйц гарах цаг уурын тааламжтай нөхцөл бүрдсэнтэй холбоотой юм.

Амьд үлдсэн эдгээр том модод нь нэгээс хоёр амьд мөчиртэй, хуурай хатсан оройтой, дарцаг хэлбэрийн муу өсөлттэй титэмтэй боловч ойн ташингын босоо бүрэлдэхүүнд оролцож, өсвөр мод олноор гарч ирэхэд тааламжтай нөлөө үзүүлж байжээ. Гэвч эдгээр нь ойн түймрийн аюулыг нэмэгдүүлж байна. Ойн түймэр гарсан тохиолдолд гадаргуугийн түймэр эдгээр модыг дамжин оройн түймэрт шилждэг тул аюултай.

Хэдийгээр 1 га-д цөөн тооны том мод ургаж байгаа боловч, өсвөр залуу моддын хөрсний чийг, үржил шимт бодисыг ямар нэг хэмжээгээр байнга хуваалцан, улмаap тэдний өсөлт, хөгжилтөнд саатуулагч нөлөө үзүүлж байна. УГ талбайн залуу ойн бүрэлдэхүүн -100Ш, 1 га-д 10.5 мян. мод ургаж, тэдгээрийн дундаж диаметр 5.6 см, өндөр 6.7 м, нөөц 95.0 м³/га байна.

Энэ бүгдээс үзэхэд, Дорнод Хэнтэйн нөхцөлд ургаж буй ямарч бүрэлдэхүүнтэй залуу шинэсэн ойн таксацын дундаж Үзүүлэлт Төв Хангайн залуу шинэсэн ойн таксацын дундаж үзүүлэлтээс ямагт их байна. Иймд Дорнод Хэнтэй нь ой мод сэргэн ургах, үүсэн бүрэлдэхэд Төв Хангайгаас илүY тохиромжтой нөхцөлтэй гэж үзэж болно.

Харин 1 га дахь модны тоогоор Төв Хангай нь үргэлж их байгаa нь тухайн нутагт ой мод үүсэн бүрэлдэж өсөж хөгжихдөө, байгаль цаг уур, экологийн эрс тэс уур амьсгалыг даван туулахын тулд олноороо нэг дор сэргэн ургаж бие биенээ эхний үед дэмжин ойн өвөрмөц орчин үүсгэж байдагтай холбоотой. Иймээс ч ой ургамалжилтийн өвөрмөц онцлог бүслүүр болох Монгол оронд төдийгүй дэлхийд ховор тайгажуу ойн бүслүүр энэ хошуунд илэрч байдаг. Тайгажуу бүслүүрийн ой мод гадны ямарваа нөлөөнд маш эмзэг тул мод бэлтгэл явуулсан зарим газар хээржиж, зарим газар дан ганц шинэсээр сэргэн ургадаг онцлогтой.

Ой үүсэн бүрэлдэх явцад ойн бүрэлдэхүүн өөрчлөгдөж моддын тоо багасдаг болохыг бидний судалгааны дүн харуулж байна. Ялангуяа 10-40 насны хооронд шинэс модны унаж хатах үйл явц ихэсч 4060 насны хооронд байгалийн аясаараа ойн сийрэгжих үйл явц буурч байна.

Төв Хангайн залуу шинэсэн ойн унангын хэмжээ 40-50 насны хооронд ихэсч, 50 наснаас эхлэн байгалийн аясаараа сийрэгжих нь багасч байна. Харин Дорнод Хэнтийн нөхцөлд 20-40 насны хооронд эрчимтэй хатжээ.

Хус-шинэсэн залуу ойн нас ахих дутам хусны өсөлт давамгайлж, шинэс модны өсөлтийг саатуулж байна. Харин шинэсхусан ой бүрэлдэх явцад (15-50 нас) ойн бүрэлдэхүүн бараг тогтмол хадгалагдаж, шинэс модны өсөлт аажмаар давамгайлна. Дан бүрэлдэхүүнтэй залуу шинэсэн 
ойн таксацын үндсэн үзүүлэлт холимог бүрэлдэхүүнтэй ойнхоос үргэлж их байна (ой-ургамалжилтийн нэг ижил нөхцөлд).

Талбайд өсвөр мод ургахдаа хэсэг бүлгээрээ бөөгнөрөн ургаж, нас ахих дутам энэ шинж чанараа алдаж талбайдаа жигдэвтэр тархан ургаж байна. Иймээс залуу ойн бүдүүний үелэлээр тархах нь «хэвийн тархалтын» муруйн хэлбэрээс өөр буюу «гиперболын юмуу экспоненциал» муруйн хэлбэртэй. Энд моддын зонхилох тархалт нь бүдүүний дундаж үелэлд биш, харин бүдүүний бага үелэлд тохиолдож, улмаар нарийн диаметртэй моддоос унаж хатах явдал их хэмжээтэй байлаа.

Түймрийн дараах ойн талбайд өсвөр мод үүсч ургах нь эхний 3-5 жилийн хугацаанд эрчимтэй явагдана. Харин мод огтолсон талбайд өсвөр мод сэргэн ургах нь 5-15 жилийн хугацаатай байгаа бөгөөд энэ нь үрийн нөөц, өвслөг ургамлан бүрхэвчийн нөлөөнөөс хамаардаг байна.

Харьцангуй нэг төрлийн залуу ой ҮҮсэх нөхцөлийг түймрийн дараах ойн талбай бүрдүүлж, өсвөр мод хэсэг бүлгээрээ сэргэн ургана. Залуу ой бүрэлдэх явцад ойн бүрэлдэхүүн, модны тоо өөрчлөгддөг. Байгалийн аясаараа ой бүрэлдэх цаашдын үйл явцад ойн нас ихсэх дутам ойн бүрэлдэхүүнд шинэсний эзлэх хэмжээ байнга дээшилдэг зүй тогтолтой билээ. Гэвч аж ахуйн үүднээс авч үзэхэд удаан хугацаагаар үнэт төрлийн бус мод ойн бүрэлдэхүүнд зонхилж, шинэс модны өсөлт хөгжилтийг саатуулж байгаа учир, шинэс модны өсөлтийг дэмжих, бүтээмжийг дээшлүүлэх зорилгоор ойн аж ахуйн зохих арга хэмжээг авч явуулах нь ашигтай юм.

Залуу шинэсэн ойн өсөлтийн явц. Ойн мод нас гүйцэх хүртлээ (насны ҮI-ҮII анги) ойн дундаж өндөртэйгээ шууд хамааралтайгаар үргэлж нэмэгддэг болох нь онолын хувьд батлагдсан асуудал билээ. Хэдийгээр тодорхой нэг талбайг хамран ургаж буй ой моддын ургах явцтай холбоотой энэхүү зүй тогтол нь байгаль цаг уур, экологийн ижил нөхцөлд ургаж буй нэг төрлийн янз бүрийн насны ойн хувьд мөн адил ажиглагддаг учир ирээдүйн ойн шинж төрхийг урьдчилан тодорхойлж тооцоолох боломжтой юм.

Бидний судалсан 15-70 насны ойд ч энэ зүй тогтол ажиглагдах бөгөөд тухайлбал: 15 настай шинэсэн ойн дундаж өндөр 3.8 м, 28 настай ойнх 7.9 м, 31 настай ойнх 9.5 м, 38 настай ойнх 15.4 м, 70 настай ойнх 18.1 м тус тус байв (1-р хүснэгт).

Харин байгаль цаг уур, экологийн өөр нөхцөлд оршиж буй ойд дээрх зүй тогтол илрэхгүй тодорхой ялгаатай байна. Тухайлбал: Төв Хангайн 42 настай, шинэсэн ойн дундаж өндөр 5.9 м байхад, Дорнод Хэнтэйн нөхцөлд ургаж буй ойролцоо насны (38 настай) шинэсэн ойн дундаж өндөр 15.4 м буюу бараг 2.5 дахин өндөр байна. Дорнод Хэнтэйн 28 настай шинэсэн ойн дундаж өндөр, Төв Хангайн 42 настай ойнхтой ойролцоо үзүүлэлттэй болох нь тогтоогдлоо. Өөрөөр хэлбэл Төв Хангайн залуу шинэсэн ойн өндрийн өсөлт нь Дорнод Хэнтийн ойнхоос 15 жил буюу бараг насны нэг ангиар доогуур байна. Ойн моддын өндрийн хэлбэлзлийн хязгаарыг тогтоосноор тухайн ойн модны өсөлт хөгжилт ямархуу хандлагатай явж байгааг илрүүлж, улмаар ойн аж ахуйд тохирох арга хэмжээг нь авч явуулах боломжтой болно. Ойн моддын өндрийн хэлбэлзлийн хязгаарыг тогтоосноор тухайн ойн модны өсөлт хөгжилт ямархуу хандлагатай явж байгааг илрүүлж, улмаар ойн аж ахуйд тохирох арга хэмжээг нь авч явуулах боломжтой.

Өндрийн хэлбэлзлийн коэффициент (вариацын коэффициент) дараах үзүүлэлттэй байна. Үүнд: 15-28 насны ойд $42.4-45.1 \%$, 31-насны ойнх 15.0-29.2\% тус тус гарлаа. Энэ нь 15-28 насандаа байгаа ойд, өндрийн хоорондын ялгарал их буйг илтгэж, уг ойд байгалийн аясаараа сийрэгжих үйл явц удааширч, өндрийн өсөлт хөгжилтөнд тааламжгүй нөлөө байгааг харуулж байна. 31-70 насны ойн хувьд өндрийн хэлбэлзлийн коэффициент дунд зэрэг байгаа нь тухайн ойд байгалийн аясаараа ойн сийрэгжих үйл явц эрчимтэй 
байгааг харуулахын зэрэгцээ тэдгээрийн өсөлт хөгжилт нь жигд болохыг нотлоно. Харин Төв Хангайн 42 настай шинэсэн ойн өндрийн хэлбэлзлийн коэффициент өндөр байгаа нь (41.5\%) уг ойд байгалийн аясаараа моддын сийрэгжих үйл явц, өндрийн өсөлтийн явц удаан байгааг илтгэнэ. Иймд энэ ойн өсөлт хөгжилтийг дээшлүүлэхэд чиглэсэн ойн аж ахуйн арга хэмжээг авч хэрэгжүүлэх шаардлагатай байна.

Төв Хангайн 42 настай шинэсэн ойн өндрийн тархалт Дорнод Хэнтэйн 28 настай ойнхтой адил хэлбэртэй, ойролцоо тархалт, далайцтай байгааг илрүүллээ. Ойн бүтцийг судлахад таксацын үндсэн үзүүлэлтийн нэг болох модны ишний бүдүүний үзүүлэлтийг тодорхойлох, түүний тархалтын зүй тогтлыг илрүүлэх нь чухал байдаг.

Моддын диаметрийн бүтэц нь: модод хоорондын бүдүүн нарийний ялгарал өөрөөр хэлбэл бүдүүний өсөлтийн эрчмийг илтгэн харуулдаг. Иймд ойн таксацын үндсэн үзүүлэлтийн нэг болох өндрийн адил ойн өсөлтийн явцын онцлогийг илрүүлэхэд чухал үүрэгтэйн зэрэгцээ ойн таксацын холбогдолтой төрөл бүрийн хүснэгт зохиоход тулгуур материал болдог.

Модны дундаж диаметр нь ойн нөөц түүнээс бэлтгэх модны хэмжээ, сортиментийн бүрэлдэхүүний баримжааг өөртөө агуулж байдаг боловч, тэдгээр нь ишнийхээ бүдүүний үелэлд хувиарлагдах байдлаараа үндсэндээ хэвийн тархалтын хуульд захирагдана.

Ойн модны дундаж диаметрийг моддын тооллогын материалыг үндэслэн математик статистик аргаар тодорхойлов. Үүнд: Дорнод Хэнтэйн 15 настай дан бүрэлдэхүүнтэй шинэсэн ойн дундаж диаметр 1.6 см, 28 настай ойнх $5.9 \mathrm{~cm}, 31$ настай ойнх $7.5 \mathrm{~cm}, 38$ настай ойнх 18.4 см, 70 настай ойнх $18.9 \mathrm{~cm}$ байв. Харин Төв Хангайн 42 настай шинэсэн ойнх 4.6 см байв.

Диаметрийн хэлбэлзлэлийн коэффициент 15-28 насны ойд (61.0-61.9\%) 38-70 насны ойгоос (13.8-25.0\%) 2-4 дахин их ут- гатай байна. Энэ нь байгалийн аясаараа ой бүрэлдэх эхний шатандаа өсвөр мод талбайд маш шигүу тархаж, тэдгээрийн хооронд амьдралын төлөө өрсөлдөөн эрчимжиж, улмаар өсөлт хөгжилтийн ялгарал их байдагтай холбоотой. Ойн амьдралын цаашдын явцад өсөлт хөгжилтөөр дорой модод үхэж, өсөлт хөгжилтөөр давамгайлсан модод үлдэж ойн моддын хоорондын ялгарал аажмаар багасан өөр хоорондоо өрсөлдөх нөлөө үгүй болж, харин ч бие биеэ дэмжин тэтгэх, үр удмаа үлдээх шатандаа шилжин ордог.

Төв Хангайн 42 настай шинэсэн ойн диаметрийн хэлбэлзлэлийн коэффициент Дорнод Хэнтэйн 15-28 насны шинэсэн ойнхтой ойролцоо байна $\quad(57.7 \%$ ба 61.0-61.9\%). Х Хэдийгээр $\quad$ хэлбэлзлэлийн коэффициент нь ойролцоо боловч бүдүүний үелэлээр моддын тархах тархалтын хэлбэр нь өөр байж болох талтай. Учир нь: бүдүүний үелэлээр модны тархах байдал тодорхой шатанд ойн наснаасаа хамаарч байдаг. Ой модод залуу насандаа их өтгөн шигүу ургаж, тэдгээрийн ихэнх хувийг бүдүүний үелэлийн нарийн диаметртэй мод эзэлж байдгаас тархалтын хэлбэр нь гиперболын тэгшитгэлийн тархалтын хэлбэртэй, харин нас ахих тусмаа байгалийн аясаараа ойн сийрэгжих үйл явц эрчимжиж, үүний үр дүнд ойн моддын ихэнх хувийг бүдүүний төвийн үелэлийн мод зонхилон эзэлж улмаар тэдгээрийн тархалтын хэлбэр Пирсоны хэвийн тархалтын хэлбэрт шилждэг зүй тогтолтой байна. Энэхүү зүй тогтол Дорнод Хэнтэйн шинэсэн ойн хувьд 30 наснаас эхэлж ажиглагдаж байхад, Төв Хангайн 40 настай ойд үл ажиглагдана. Энэ нь тухайн 2 районы ой мод байгаль цаг уур, экологийг өөр нөхцөлд ургаж, өсөж байдагтай шууд холбоотой. Ойн бүтцийн бүрэлдэхүүнд модны титмийн диаметр, титмийн уртын үзүүлэлт багтдаг. 
Судалгаа явуулсан нутгийн ойн таксаиьн бүтщийн зарим ҮзҮҮлэлт

\begin{tabular}{|c|c|c|c|c|c|c|}
\hline \multirow[b]{2}{*}{ 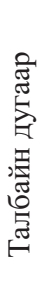 } & \multirow[b]{2}{*}{ Таксацын үзүүлэлтүүд } & \multicolumn{5}{|c|}{ Статистик үзүүлэлтүүд } \\
\hline & & 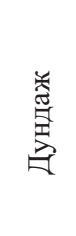 & 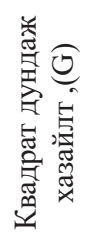 & 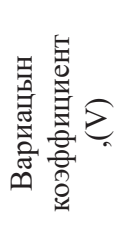 & 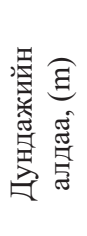 & 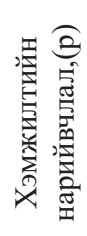 \\
\hline \multicolumn{7}{|c|}{ Дорнод Хэнтэй } \\
\hline \multirow{3}{*}{4} & Ойн нас (А), жил & 15.1 & 2.67 & 17.7 & 1.01 & 6.69 \\
\hline & Өндөр(Н), м & 3.8 & 1.61 & 42.4 & 0.10 & 2.60 \\
\hline & Диаметр(D), см & 1.6 & 0.99 & 61.9 & 0.06 & 3.87 \\
\hline \multirow{3}{*}{2} & Ойн нас (A), жил & 28.1 & 5.14 & 18.4 & 1.29 & 4.59 \\
\hline & Өндөр(Н), м & 7.9 & 3.56 & 45.1 & 0.22 & 2.76 \\
\hline & Диаметр(D), см & 5.9 & 3.60 & 61.0 & 0.22 & 3.77 \\
\hline \multirow{3}{*}{5} & Ойн нас (A), жил & 30.7 & 2.22 & 7.2 & 0.40 & 1.30 \\
\hline & Өндөр(Н), м & 9.5 & 1.73 & 18.2 & 0.22 & 2.34 \\
\hline & Диаметр(D), см & 7.5 & 2.71 & 36.1 & 0.22 & 2.97 \\
\hline \multirow{3}{*}{1} & Ойн нас (А), жил & 38.2 & 5.70 & 14.9 & 1.80 & 4.72 \\
\hline & Өндөр(Н), м & 15.4 & 4.49 & 29.2 & 2.26 & 1.72 \\
\hline & Диаметр(D), см & 18.4 & 2.53 & 13.8 & 0.15 & 0.82 \\
\hline \multirow{3}{*}{3} & Ойн нас (A), жил & 69.8 & 4.12 & 5.9 & 1.46 & 2.09 \\
\hline & Өндөр(Н), м & 18.1 & 2.72 & 15.0 & 0.22 & 1.20 \\
\hline & Диаметр(D), см & 18.9 & 4.72 & 25.0 & 0.39 & 2.08 \\
\hline \multicolumn{7}{|c|}{ Төв Хангай } \\
\hline \multirow{3}{*}{11} & Ойн нас (A), жил & 42.3 & 6.2 & 14.2 & 0.42 & 0.98 \\
\hline & Өндөр(Н), м & 5.9 & 2.5 & 41.5 & 0.17 & 2.86 \\
\hline & Диаметр(D), см & 4.6 & 2.7 & 57.7 & 0.18 & 3.98 \\
\hline
\end{tabular}

Титмийн диаметрийн бүтэц. Титмийн диаметрийн тархалтаар 15 ба 31 настай ойнх хоорондоо маш ойролцоо, бараг нэг адил далайцтай (0.5-2.0 м), тархалтын төвийн үелэлээс нэг талруугаа харсан огцом бууралттай байна. Харин бусад талбайн ой моддын хэлбэлзлийн далайц 6 м хүрч,төвийн үелэлээс хоёр тийш жигд буурсан, үлэмж сунасан хэлбэртэй байлаа. Энэ нь тухайн насны ойн нэгж талбай дахь модны тоо харьцангуй их байгаагаас тэнд ургаж буй моддын титмийн диаметрийн өсөлт, хөгжилт удаан байгаатай холбоотой. Өөрөөр хэлбэл модны титмийн өсөлт хөгжилт нь ойн наснаас бус нэгж талбай дахь модны тооноос шууд хамаардаг онцлогтойг харуулна. Тухайлбал, 28 настай ойн 1 га талбайд 5.2 мян. мод ургаж, тэдгээрийн титмийн дундаж диаметр 1.6 м, 31 настай ойн 1 га-д 9.1 мян. мод ургаж, титмийн дундаж диаметр нь 1.1 м байна. Мөн түүнчлэн 70 насны ойн хувьд ч энэ зүй тогтол өөрчлөгдөхгүй (2-р хүснэгт).

Эдгээр бүх зүй тогтол нь модны титэмд тусаж буй гэрлийн хэмжээтэй шууд холбоотой. Өөрөөр хэлбэл шигүүрэл багсахад модны титэмд тусах гэрлийн хэмжээ ихсэж, үүний үр дүнд мөчир, шилмүүсний өсөлт нэмэгддэг.

Дээр дурдсан морфологи үзүүлэлтүүдийн хоорондын харилцан хамааралд регресийн шинжилгээ хийж, үр дүнг тахирмаг ба гистограммаар дүрслэн үзүүллээ (1 ба 2-р зураг).

Ойннөөцийнбүтэцнь:мододхоорондын эзлэхүүний ялгаа тухайлбал, модод 
хоорондын хэлбэр хэмжээний ялгарлыг өгүүлж байдаг таксацын хамгийн чухал үндсэн үзүүлэлт юм. Ойн нөөц нь моддын өндөр, диаметр хоёртой шууд хамааралтай бөгөөд энэхүу хоёр үзүүлэлтийн нэгдсэн үр дүнгээр тодорхойлогддог. Ойн нөөцийн бүтэц нь өндрийн бүтэц, диаметрийн бүтэц хоёрыг өөртөө агуулж байдаг учир ой судлалын олон асуудлыг боловсруулахад шийдвэрлэх үүрэг гүйцэтгэдэг.

Ойн нөөц нь таксацын бүтцийн хамгийн чухал үзүүлэлтийн нэг учраас онол-практикийн ихээхэн ач холбогдолтой. Ойн нөөцийн тархалтын зүй тогтолыг илрүүснээр, тухайн бүс нутагт ойн аж ахуйн ямар арга хэмжээг хэдэн настайд нь явуулах шаардлагатайг урьдчилан мэдэж болно.

Судалгааны дүнгээс үзэхэд, Дорнод Хэнтэйн 15 настай шинэсэн ойд гэрэлжүүлэх огтлолт (осветление) явуулах шаардлагагүй, харин 28-31 насны ойд тохируулах огтлолт (прочистка), 38 настай ойд сийрэгжүүлэх огтлолт (прореживание), 70 настай ойд завсрын огтлолт (проходное) явуулах хэрэгтэй байна.

Эдгээр огтлолтын хэлбэр нь ойн шигүүрлийг зохицуулах, бүтэц, бүрэлдэхүүнийг сайжруулах, өсөлт хөгжилтийг дээшлүүлэх зэрэг тус бүрдээ тодорхой олон зорилт агуулсан байдаг.

Төв Хангайн 40 настай ойн нөөцийн тархалтын явц нь Дорнод Хэнтэйн 30 настай ойн нөөцийн тархалтын хэлбэртэй адил байна. Энэ нь Төв Хангайн ой модны өсөлт хөгжилт нь Дорнод Хэнтийн ойгоос насны хагас анги буюу 10 жилээр хоцорсон өвөрмөц онцлогтойг харуулна.

\section{ДҮГНЭЛТ}

Төв Хангай, Дорнод Хэнтэйн залуу ойд олон жил явуулсан судалгааны дүнд сибирь шинэсэн залуу ойн моддын өсөлт хөгжилтийн талаар илрүүлсэн зарим зүй тогтол нь залуу ой үүсэн бүрэлдэх үйл явцыг тоо, хэмжээгээр тодорхойлох бодит боломжийг өгч, улмаар ойн аж ахуйг хөтлөн явуулах шинжлэх ухааны үндэс болж байна.

Төв Хангай, Дорнод Хэнтэйн залуу шинэсэн ой үндсэндээ насаар чацуу болохыг тогтоов. Энэ нь ойн модны насны хэлбэлзлэлийн коэффициентын утга 5.9$17.4 \%$ байгаагаар нотлогдоно.

Манай оронд 20-25 жилийн завсарлагатай тохиолддог цаг уурын тохиромжтой үед шинэсэн ойгоос мод огтолсон,түймэртшатсанталбайдянзбүрийн бүтээмжтэй, холимог бүрэлдэхүүнтэй байгалийн залуу ой үүсэн бүрэлдэж байна. Тэдгээрийн үүсэн бүрэлдэх явц нь далайн түвшинээс өргөгдөх үнэмлэхүй өндөр, цаг уурын эрс тэсийн түвшин, ойн түймэр, мод огтлолтын эрчим, мөн тэрчлэн эх ойн моддын нөлөө зэргээс ихээхэн шалтгаална.

Ургах орчны янз бүрийн нөхцөл дэхь шинэс моддын өсөлтийн онцлогийг харгалзан үзэж тэдгээрийн бүтцийн талаар илрүүлсэн зүй тогтолыг ойн таксацид ашиглах боломжтой юм. 


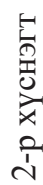

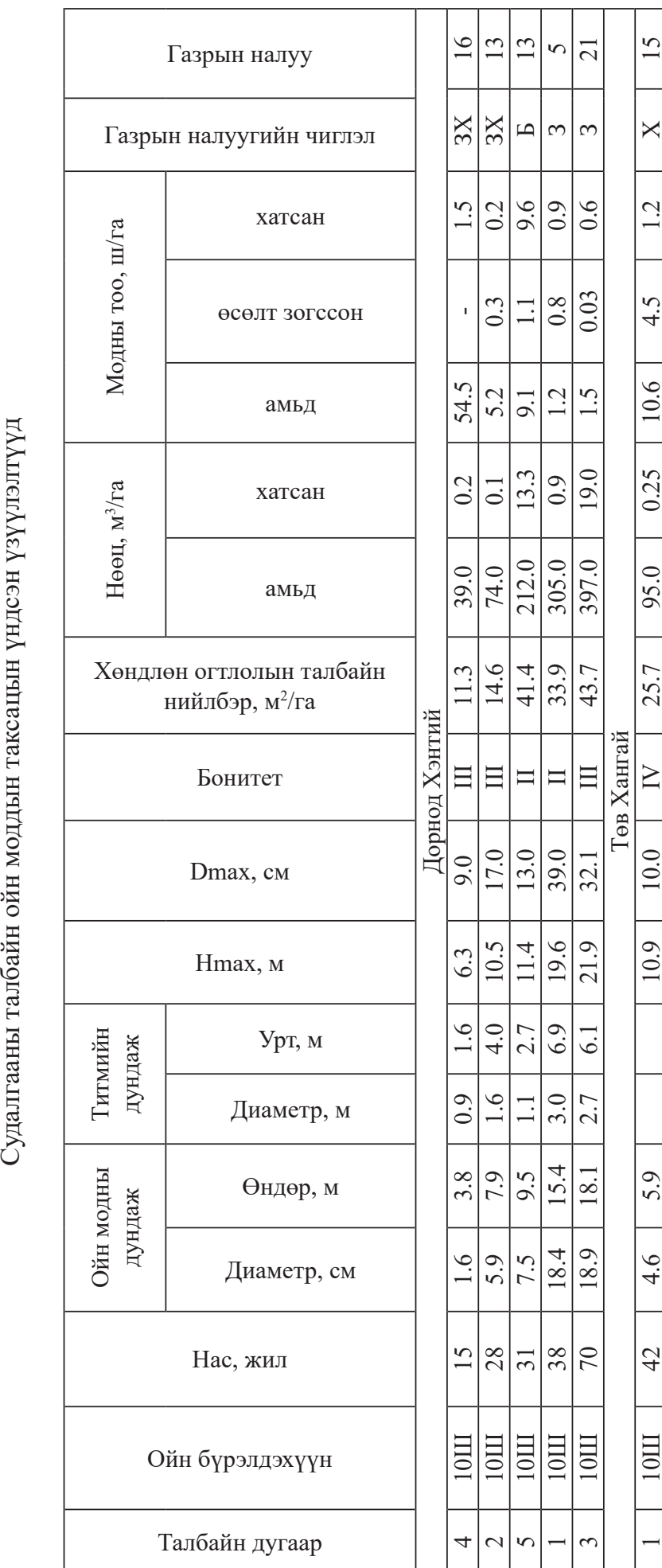

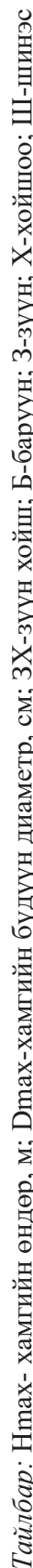


a)

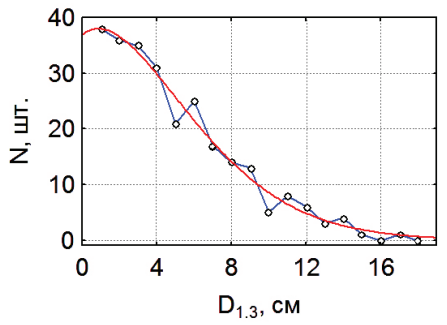

г)

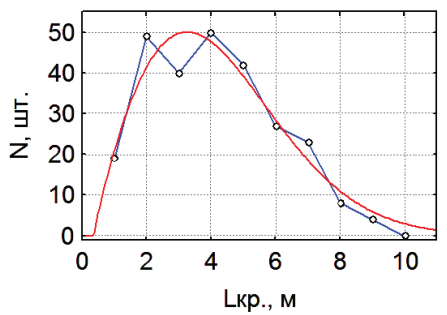

б)

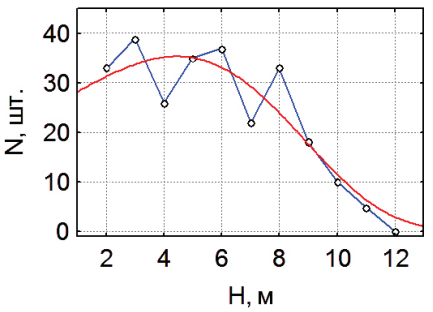

д)

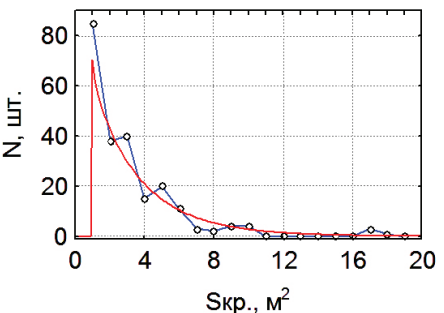

B)

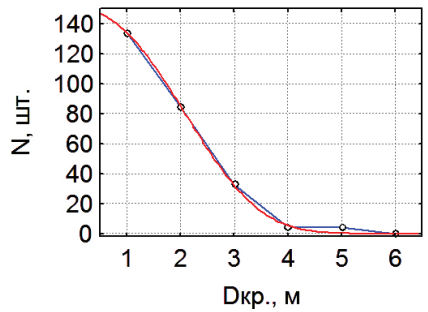

e)

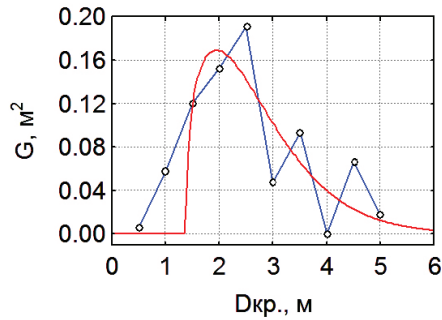

1-р зураг. Дорнод Хэнтэйн 28 настай шинэсэн ойн моддын тархалт ба ишний морфологи үзүүлэлтүүдийн хоорондын хамаарлын тахирмаг.

а) бүдүүний үелэлээр модны тооны тархалт ( $\mathrm{N}$-модны тоо,шт., $\mathrm{D}_{1.3},-$ диаметр, см)

б) өндрийн үелэлээр модны тооны тархалт ( $\mathrm{N}$-модны тоо,шт., H - өндөр, м)

в) титмийн диаметрийн үелэлээр модны тооны тархалт ( $\mathrm{N}$-модны тоо шт., Dкр. -титмийн диаметр, м)

г) титмийн уртын үелэлээр модны тооны тархалт (N -модны тоо, шт., Lкр. Титмийн урт, м)

д) титмийн хөндлөн огтлолын талбайн үелэлээр модны тооны тархалт (N -модны тоо шт, Sкр. -титмийн тойргийн талбай, м $^{2}$ )

е) титмийн диаметр, ишний хөндлөн огтлолын талбайн нийлбэрийн хоорондын хамаарал- G $f$ (Dкр.). 

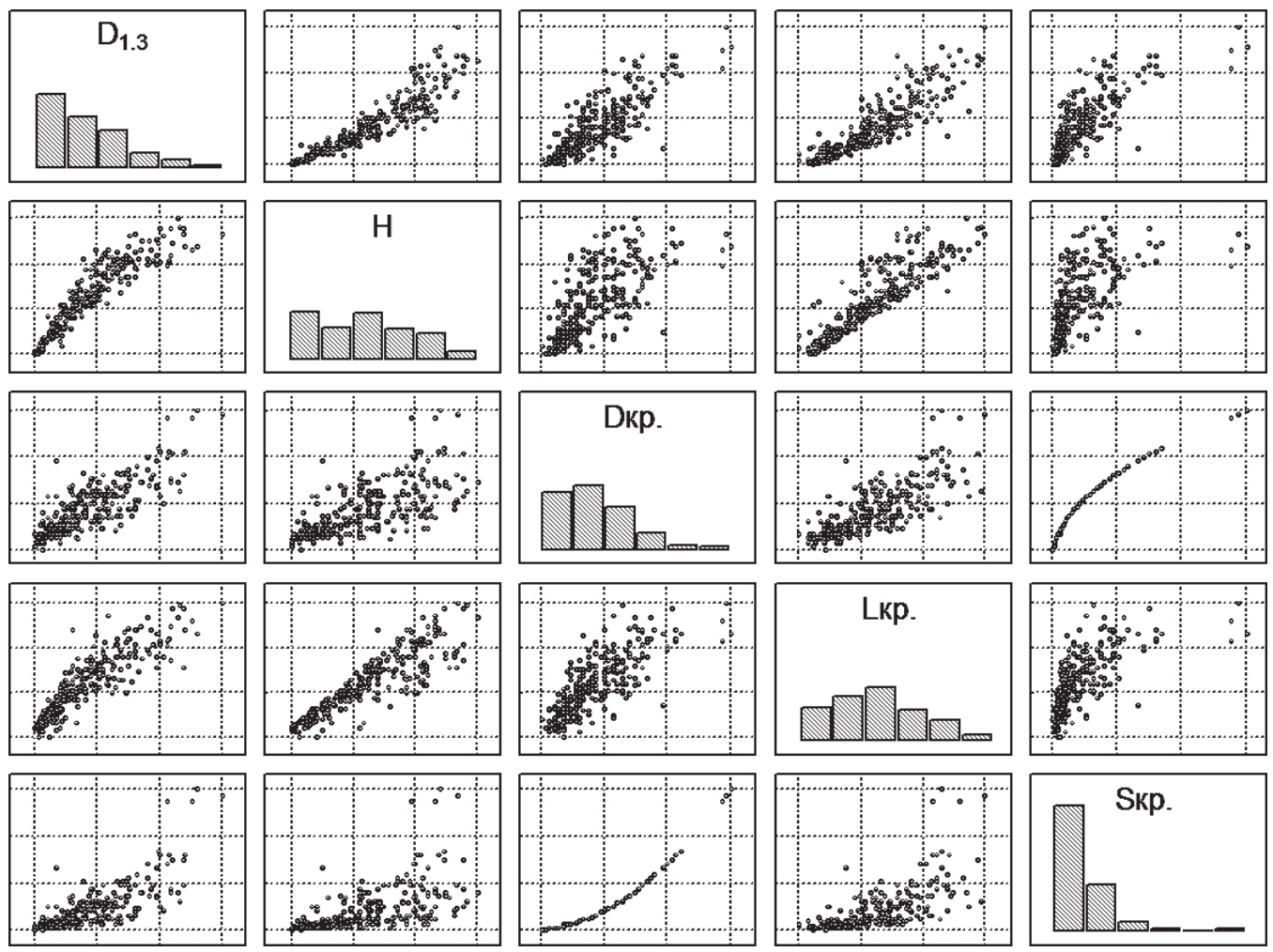

2-p зураг. Дорнод Хэнтэйн 28 настай шинэсэн ойн моддын морфологи үзүүлэлтүүдийн хоорондын хамаарал ба тархалтыг харуулсан гистограмм.

( $\mathrm{D}_{1.3}$ - диаметр, см; H -өндөр, м; Dкр -титмийн диаметр, м;

Lкр -титмийн урт, м; Sкр -титмийн тойргийн талбай, M $^{2}$ ) 


\section{Ашигласан бүтээлийн жагсаалт}

1. Анучин Н.П. 1977. Лесная таксация. М.: Изд-во, Лесн. Пром. 512 с.

2. Букзыкин А.И. Пщеничникова Л.С. Рубки ухода в сосново-лиственных молодняках ЮгоЗападного Приангарья. В кн.: Формированние и продуктивность древостоев, Наука, Новосибирск, 1981, С.91-117

3. Данилин И.М. Структура органической массы и биопродуктивность насаждений Larix sibirica Ledeb. на южном пределе их распространения в Монголии // Раст. рес., 1992, 28(1). C. 111-117.

4. Данилин И.М., Цогт 3. Антропогенная динамика лиственничников Восточного Хэнтэя // Экол. и природопольз. в Монголии. Сб. науч. тр. Пущино: Пущинский науч. центр РАН, 1992. С. 249-259.

5. Данилин И.М. Структура послепожарных березняков на южном пределе распространения // Лесоведение, 2009, № 3. С. 20-31.

6. Ч.Доржсурэн Ч. Антропогенные сукцесии в лиственничных лесах Монголии. М.,2009. $209 \mathrm{c}$.

7. Дугаржав Ч. Лиственничные леса Монголии (Современное состояние и воспроизводтва): Автореф. дисс. ... доктора. биол. наук: - Красноярск: ИЛ СО РАН, 1996. - 59 с.

8. Ермоленко П.М. Формирование состава Хвойно-лиственных молодняков на вырубках кедровников в черневом подпоясе западного Саяна. -В кн.: Формирование ипродуктивность древостоев. Наука, Новосибирск. 1981, С. 53-71

9. Калинин В.И. Лиственница Европейского Севера. М.Лесная пром. 1965. 91 с

10. Конев Г.И. Естественное возобновление на концентрированных вырубках в Тайшетском и Пойменском лесхозах. - Бюл. науч. -техн. информации СИБНИИЛХЭ, 1958. N 1-2, С. 31-36.

11. Колесников Б.П., Смолоногов Е.П. Некоторые закономерности возрастной и восстановительной динамики кедровых лесов Зауралького Приобья. -"Труды по лесному хоз-ву Сибири" 1960, вып. 6. С. 21-23.

12. Коропаченский И.Ю. Естественное лесовосстановление вырубок в сосновых лесах Иркутской области. -Тр. СИБТИ, 1964, вып. 5, С. 123-137.

13. Кайрюкштис Л.А. Метод составления таблиц хода роста смешанных и сложных насаждений. Каунас . 1969. 15 с.

14. Поликарпов Н.П. Формирование сосновых молодняков на концентрированных вырубках. М.: Наука, 1962. 171 с.

15. Побединский А.В. Изучение лесовозобновительных процессов. М.: Наука, 1966. 64 с.

16. Пшеничникова Л.С. Формирование и рост сосново-лиственных молодняков Приангарья // Формирование и продуктивность древостоев. Новосибирск, Наука, 1981. С. 71-90.

17. Савин Е.Н. Лесовосстановление светлохвойных лесов МНР (природа лесовозобновления, лесоводственные мероприятия). Дис. в форме науч. докл. докт. с.-х. наук: 06.03.03. Красноярск: ИЛиД СО АН СССР, 1985. 50 с.

18. Савин Е.Н., Лоскутов Р.И. Естественное возобновление в сосняках левобережья р. Ангара (в пределах Красноярского края) // Рубки и возобновление в лесах Сибири. Красноярск: Красноярское кн. изд-во, 1961. С. 53-74.

19. Седых В.Н. Формирование кедровых лесов Приобья. Новосибирск: Наука, 1979. 110 с.

20. Цогт 3. Формирование, строение и продуктивность лиственничных молодняков Центрального Хангая и Восточного Хэнтэя и рубки ухода в них. Автореф. дис. ... канд. с.-х. Наук, Улан-Батор: Ин-т ботан. АН МНР, 1993. 24 с.

21. Ярмишко В.Т., Дугаржав Ч., Слемнев Н.Н., Доржсүрэн Ч., Потокин А.Ф., Цогт 3., Зоёо Д. Современные возобновительные и сукцессионные процессы в лиственничных лесах Монголии // Экологические последствия биосферных процессов в экотонной зоне Южной Сибири и Центральной Азии. Улан-Батор, 2010. С.183-186. 


\section{Abstract \\ PROCESS OF YOUNG LARCH FORESTS EMERGING FORMATION AND SOME GROWTH DEVELOPMENT CHARACTERISTICS IN MONGOLIAN}

Tsogt Z., Danilin I.M

In this paper, we discussed the results of 32 years study of the formation of larch forest and their growth dynamics in Mongolia.

We found some patterns and trends in the dynamics of growth and development of young Siberian larch forests during this long term study in young forests of Central Khangai, and Eastern Khentii. This would be of tremendous help in determining and quantifying the forest development processes, and further be a scientific basis of forest management practice.

The study revealed that the young larch forests in Central Khangai and Eastern Khentii are even aged. This is proven by the tree age variation coefficient $(5.9-17.4 \%)$.

In Mongolia, natural young larch forests emerge to form with different productivity levels and species composition mixtures at larch-logged and burnt forest areas due to occurrence of favorable weather condition at interval of every 20-25 years. Structural formations and species composition of these forests are highly dependent on altitude, abruptness of extreme weather condition, intensity of logging and influence of surrounding forests.

Structural patterns and trends revealed here considering growth characteristics of larch forests grown in different site conditions are possible to be applied in forest mensuration. 